\title{
A SEMIOTIC ANALYSIS FOUND ON KOPI KAPAL API SPECIAL MIX RAMADHAN EDITION ADVERTISEMENT
}

\author{
Mukhlasul Fasikh \\ mukhlasul@stibaiecjakarta.ac.id \\ Sekolah Tinggi Bahasa Asing- IEC Jakarta
}

\author{
Abdul Muhid Murtadho \\ Sekolah Tinggi Bahasa Asing- IEC Jakarta \\ muhid@stibaiecjakarta.ac.id
}

Fasikh, M and Murtadho, A.M. (2020). A semiotic analysis found on kopi kapal api special mix ramadhan edition advertisement. Journal of English Language and literature, 5(2), 41-48. doi: 10.37110/jell.v5i02.103

Abstract: In this study, the writer did a semiotic analysis towards the advertisement in television. The qualitative research method with content analysis approach is used because this study needs deeper analysis of the content where in this study was semiotic signs. It is found that the man in the picture is very special. He delivers happiness and togetherness condition. The happiness and togetherness are most displayed in this advertisement. Happiness is shown when People are able to start to chat without any gap easily and happily. Togetherness is displayed when people gather together in the café. The other sign is the strong aroma of the coffee that reminds the man about his past.

Keywords: advertisement, happiness and togetherness, semiotic analysis,

\section{INTRODUCTION}

A language is the source of human life where it is used to share the information and to express their feeling, knowledge, belief, behavior, ideas and desires. According to Wardhaugh (2010), language is a system arbitrary vocal symbol used for human communication. Communication is the exchange of ideas or the process of establishing a commonness or oneness of thought between a sender and receiver (Belch and Belch, 2004).

The development of language and lifestyle in society can be physically observed. Like the drinking coffee lifestyle that has been growing recently. A growing lifestyle can create a new phenomenon, a need and also a commodity. The rise of drinking coffee life style influences the emergence of many brands of coffee products. Moreover, many brands nowadays promote their products through the media in mass communication.

One of the media in mass communication is television. Television's content such as news program, information, entertainment, and advertising, has strength influence to audience. As a means of promotion, broadcast television advertising based on the Law No. 32 of 2002 about 
Broadcasting consists of commercial advertisements and public service announcements. For commercial advertisers, television is a complementary means for business development. Products offered in a commercial on television broadcasts consist of various brands and types. The concept of products customized to consumers' target. If a promoted product is aimed at male consumers, then the things that are closely relate to the man who would become the symbol in the display advertising. Similarly, products that target female consumers, then it strongly associated with women who will be highlighted.

One of the special products for drinking coffee which takes advantage of this man lifestyle phenomenon is Kopi Kapal Api special mix that creates a coffee in a sachet with special mix coffee and sugar inside. It is produced by Santos Jaya Abadi Company located in Sepanjang Sidoarjo East Java. This product in advertisement has many signs with certain meanings than brings different understanding for the audiences. This advertisement is taken from Iklan TV Indonesia $H D$ YouTube Channel published on May $1^{\text {st }}, 2020$. The title on Youtube is "Iklan Kopi Kapal Api Edisi Ramadhan (ft. Ario Bayu-2020)".

This Kopi Kapal Api advertisement is published in the Pandemic Covid-19 together with the Ramadhan month (1441 H). It's the holy month for Muslims to have fasting. During that time, many people are instructed by the government to stay at home rather than to go around out of their houses. There is recalling moment in the content of this advertisement such as comparing this Ramadhan and the previous Ramadhan with different activities.

The signs used in the advertisements are diverse and have certain meanings. Aside from attracting attention, signs in the advertisements will bring the understanding of a particular message for the audience. There are codes that create actions. In addition to physical delivery, the advertisements also try to deliver message through language or text which tells us to understand the meaning of the images in the advertisements.

In communication, sign has taken a part in human surrounding. Perlmutter (2011) argued that human uses the sign or symbol to communicate to the other people who have the same feeling, idea, and desire where the communicator agreed about a sign system. However, not all people can be able to interpret the meaning of sign. That's why the study of meaning of the signs we called semiotic exist. It's to help people understand about the sign as the communication way.

Based on the problem in this research, the objective is that researcher intends to find out how the signs and meanings symbolized in the Kopi Kapal Api Special Mix Ramadhan Edition Advertisement.

\section{A. The Semiotics Concept}

According to Mayr (2013), the term semiotics (often also referred to as'semiology') derives from the Greek word semeion meaning 'sign'. It is the study of signs and symbols that focused on words, any communicative element from an image to a hairstyle counts as a sign. As for that, the writer believe that Semiotic is the study of meaning of sign that help people to gathering more information and communicate better and efficient through the signs around.

Tinarbuko (2008: 13) "a sign (in the form of word or image) has two aspects, the one that is captured by the human sense is called signifier (form) and another aspect called signified (concept or meaning)". The second aspect is contained in the first aspect. So a concept is what the first aspect has to present.in line with the previous one, semiotic is one of the study that become a tradition in the study theory of communication. Semiotic tradition consists of a set of theories about how the signs represent objects, ideas, circumstances, situations, 
feelings and conditions outside the sign itself (Littlejohn, 2009: 53).

\section{B. Roland Barthes' Analysis of Semiotic}

Roland Barthes is a figure that is so synonymous with the study of semiotics. Barthes semiotic thought could be said of the most widely used in research. Barthes thought about the concept of the famous semiotic mythologies concept or myth. As the successor of the Saussure thought, Roland Barthes emphasizes the interaction between the text with personal and cultural experience of its users, the interaction between the conventions in the text to the conventions experienced and expected by the users (Kriyantono, 2007: 268).

According to Roland Barthes, advertisements were analyze based on the message contains, namely:

1. Message Linguistics: All the words and phrases in the advertisement

2. Messages encoded: connotation that appears in the advertisement photo

3. Iconic message that is not encoded: Denotation in advertising photos

Figure 1. Roland Barthes Sign Map

\begin{tabular}{|l|l|l|}
\hline $\begin{array}{l}\text { 1. } \begin{array}{l}\text { Signifier } \\
\text { (penanda) }\end{array} \\
\text { 3. Denotative Sign (tanda denotatif) } \\
\text { (petanda) }\end{array}$ & \\
\hline 4. Connotative Signifier \\
(penanda konotatif) & $\begin{array}{l}\text { 5. Connotative Signified } \\
\text { (petanda konotatif) }\end{array}$ \\
\hline 6. Connotative Sign (tanda konotatif)
\end{tabular}

On the map it is explained that the denotative sign (3) consists of signifier (1) and signified (2), and at the same time denotative sign is also a connotative sign (4). For example, the word "lion" has connotations such as ferocity, courage, and perhaps respect (Sobur, 2013: 68).

The purpose of semiotic is to determine the meanings contained in a sign or interpret the meaning how the communicators construct the messages. The concept of this meaning is inseparable from the perspective or the particular ideological values and cultural concepts into the realm of people's minds where the symbol was created. The meaning of that construction became the basic for the establishment of a sign in ideology.

\section{METHOD}

This research uses qualitative research methodology. Sugiyono
(2009:306) claimed that "the researcher in qualitative research is as human instrument; his function is to determine the research focus, to determine the informant as source of data, to collect data, to assess quality of data, to analyze data, to interpret data and to conclude of the findings".

The object of this research is is Kopi Kapal Api special mix Ramadhan Edition advertisement. The title on Youtube is "Iklan Kopi Kapal Api Edisi Ramadhan (ft. Ario Bayu-2020)". This advertisement is taken from Iklan TV Indonesia HD YouTube Channel published on May $1^{\text {st }}$, 2020. The researcher interprets the data from the advertisement using Roland Barthes theory.

This type of research is semiotics analysis on advertisement by Roland Barthes. Semiotics focuses on the role of communication in stabilizing and maintaining values and how those values enable communication to have meaning. 
Mukhlasul Fasikh \& Abdul Muhid Murtadho

A semiotic analysis found on kopi kapal api special mix ramadhan edition advertisement

Barthes analyzes the advertisement by using denotative and connotative analysis which then found myths to clarify the meaning of advertisement through the signs.

\section{FINDINGS AND DISCUSSION}

This Kopi Kapal Api special mix Ramadhan Edition advertisement is a commercial advertisement of special mix coffee with sugar for all kinds people. This advertisement is created in 30 minutes of duration. This ad tells the story of a man who enjoys coffee in different way because of the different condition.

One day, a man woke up at 3 early in the morning. Then he made a cup of coffee from Kopi Kapal Api Special mix. While he was starting to drink and smelling the aroma of coffee, he was reminded the same situation one night when he was in a café. He made some cups of coffee and called anyone who passed to join together enjoying the coffee inside. He did happily with them while talking in the café with the special mix one.

The constructed message on happiness and togetherness in drinking coffee is delivered with words, facial expressions, color, body languages, and styles. And also the same strong aroma of coffee is shown.

Table 1. Semiotic analysis of Kopi Kapal Api special mix Ramadhan Edition advertisement

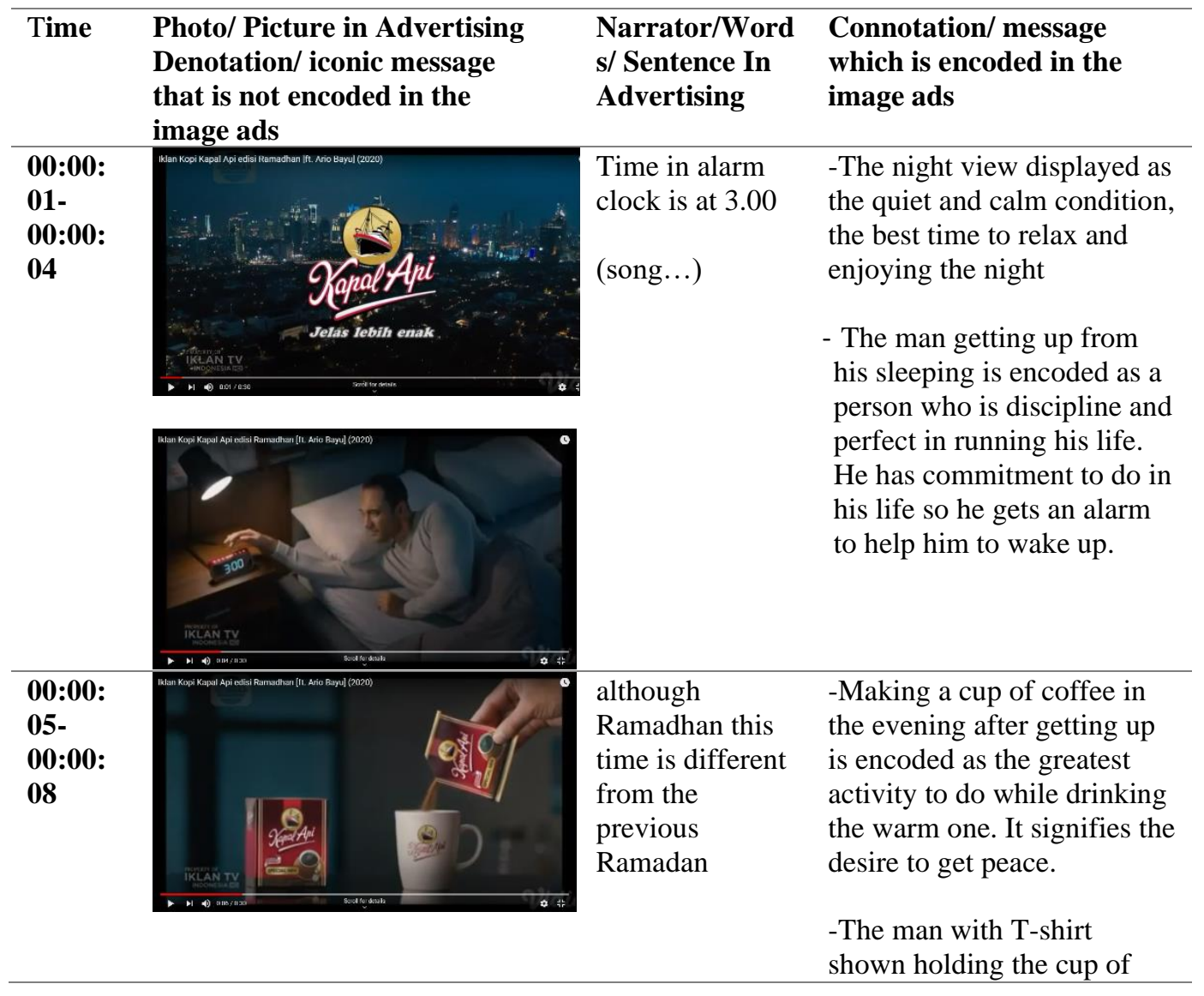



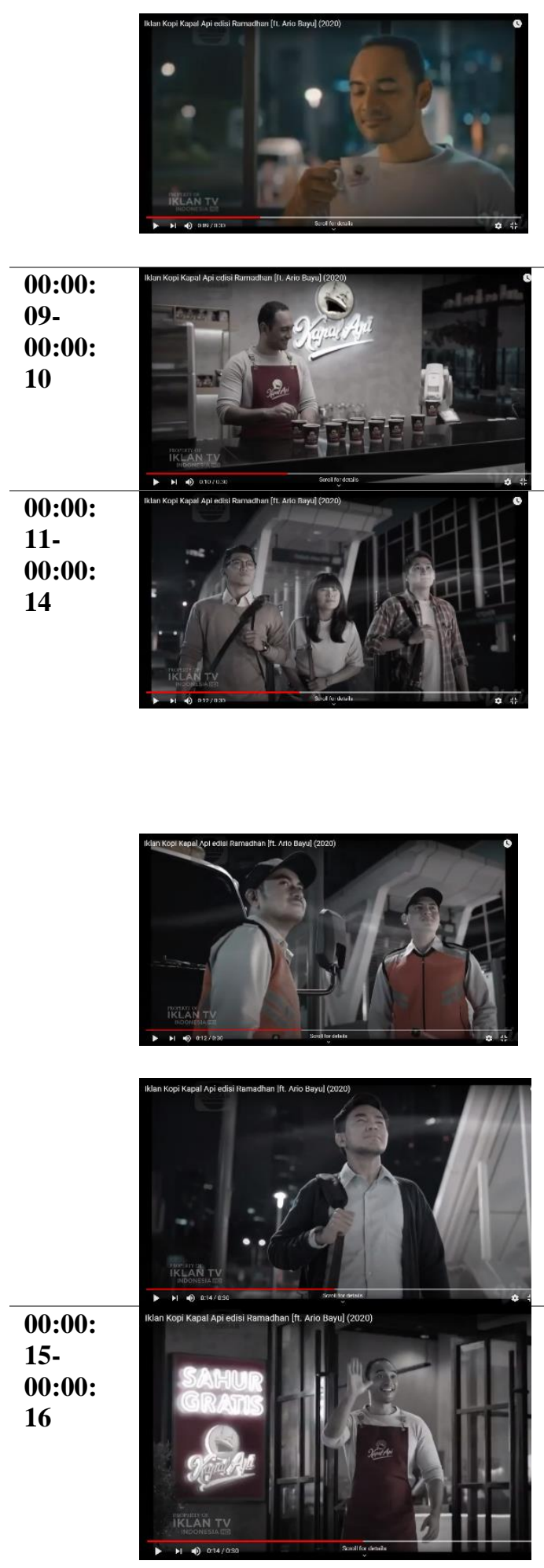

coffee and smelling is enjoying the strong aroma and reminding his past moment in Ramadhan. It gives sign of tasteful, passionate and optimistic. Also the taste or aroma of coffee is strong enough.

make us miss - The man displayed the past moment in the café is making some cups of coffee. It signifies that he is taking care of customers well.

the beauty of $\quad-3$ young People are shown sharing the walking on the sidewalks aroma and smelling the aroma of special taste of Kopi Kapal Api coffee. It gives a sign that the aroma is very strong and interests the people who pass the café.

-The 2 workers displayed as ones who are interested the smell of the strong aroma of coffee. It signifies that the aroma is very delicious and it needs to be tried

-The officer appears as one who smells the different aroma of the coffee. It gives signs that the aroma of coffee is very delicious to try

Kopi Kapal Api -The man shown as a waiter of coffee waves his hands to the people outside. It signifies that he is kind and enthusiastic to invite people to taste his best product of coffee.

-Many people with different background of job displayed as the ones who are eagerly to go to the café. It gives sign that their mood to try 
Mukhlasul Fasikh \& Abdul Muhid Murtadho

A semiotic analysis found on kopi kapal api special mix ramadhan edition advertisement
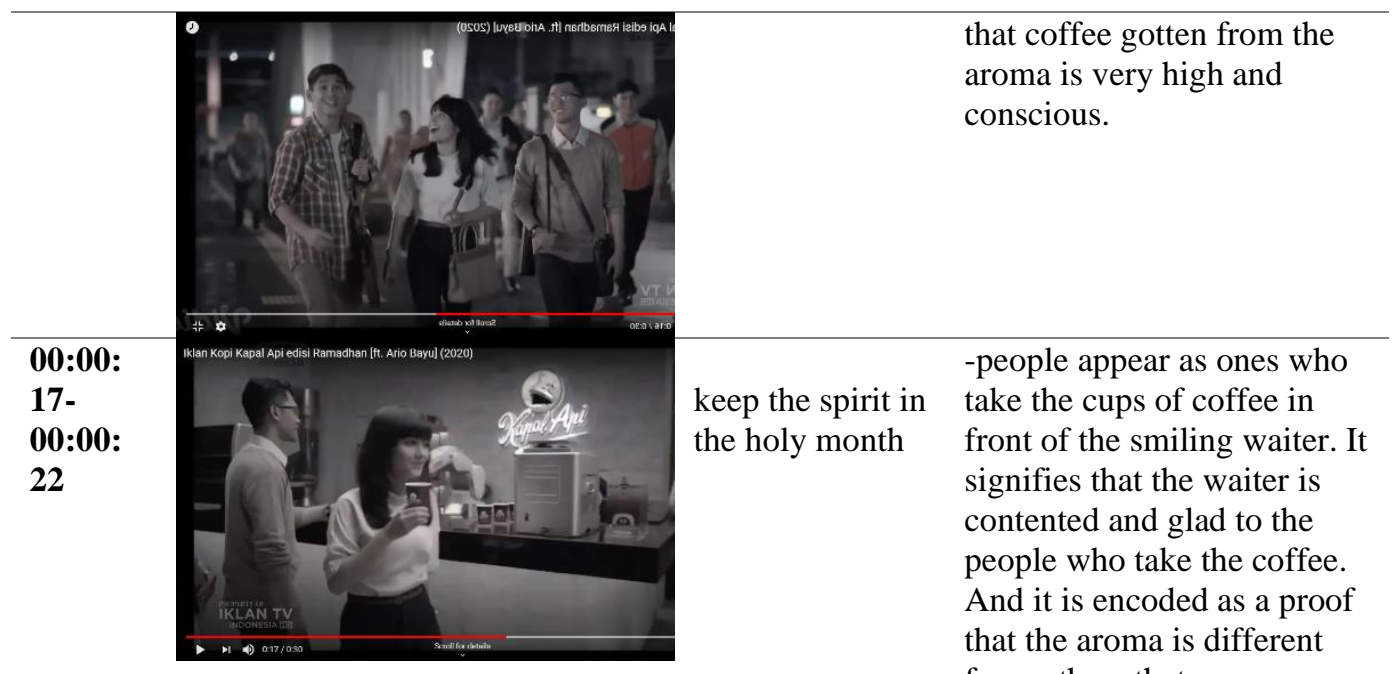

keep the spirit in take the cups of coffee in the holy month front of the smiling waiter. It signifies that the waiter is contented and glad to the people who take the coffee. And it is encoded as a proof that the aroma is different from others that emerge spirit to try.

-The waiter shown as one who greets the customers on their table. It is encoded as

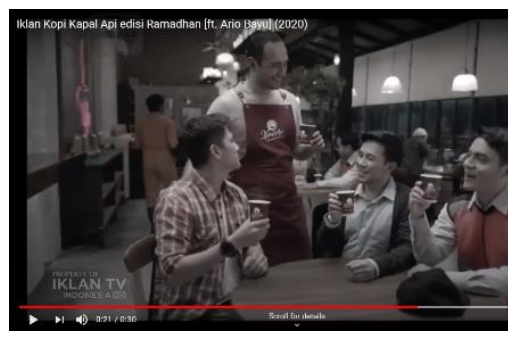
that building communication and starting to communicate even with different background of job is easy way as long as you enjoy with the same thing, such as drinking coffee

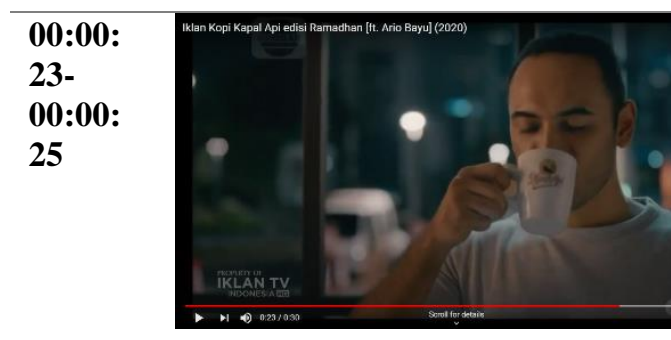

With Kopi
Kapal Api at
home

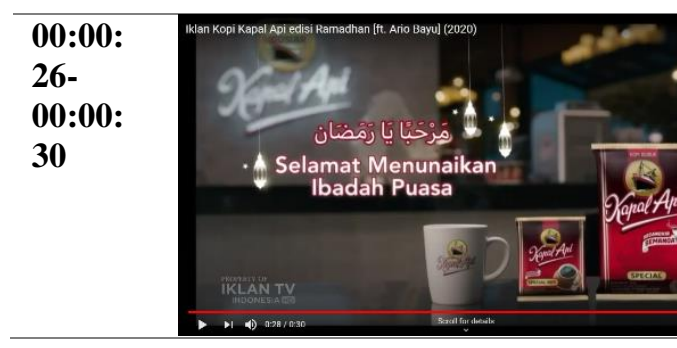

It's obviously better

-The man appears as the one who drinks coffee while closing his hand. It gives a code that the man knows more the way in drinking and in enjoying it wherever they are even he is at home. And it signifies that the way in drinking coffee is different from others -2 sachets of coffee and a cup of coffee are encoded as the simplicity for everyone who wants to enjoy coffee even he is at home. It delivers a sign of better enthusiasm and obviously better taste.

The man in this ads is as an actor who delivers happiness and togetherness condition. He tries to share the great experience in making coffee well even he is at home. he appears in the ads as a confident, enthusiastic, kind, warmth and cheerful. 
From this ads, happiness is easy to get for everyone nowadays. This person just makes some coffee, and the aroma has invited them to come. Then, he invites some people from different background to join in his café. They start to build the communication smoothly. It means that by having a coffee together from this ads, the message there is happiness which is people are able to start to chat without any gap easily and happily.

The togetherness from this ad is shown when people are in the café. They gather together for same reasons. One of them is that they drink coffee and chit chat cheerfully and enthusiastically. This experience is seen in the ad to show that having the coffee at home can be obviously better and remind the best experience with some people that you are not able to forget.

The strong aroma of coffee is displayed on some pictures. There are about

4 displayed images. They encoded that the strong aroma of coffee that is produced from the cup of coffee is very delicious and invite some people to try it. It's interpreted that the aroma of strong coffee doesn't change. Even though they make it from his house, the aroma's still same when they made it in the café.

\section{CONCLUSION}

The advertisement of Kopi Kapal Api special mix Ramadhan Edition constructs happiness and togetherness through the signs of linguistic message in the form of photographs or image in advertising, words and sentences in advertisements. And also the same strong aroma of coffee is displayed. The connotation meaning is encoded in the image of advertisement and the message iconic is not encoded in the advertising image.

Happiness is one of the first sign that is shown in the advertisement. It is displayed starting from the man who is getting up then making a cup of coffee. From his face encoded that he doesn't have problem. He just reminds the moment of togetherness in the past activities when he was in the café.
The display picture in advertisement shows many people gather in the café while drinking coffee. It's sign that depicted through connotation in the form of coded messages. It is indicated that gathering people in the display picture in ads is togetherness among others. They starting their communication among others without any gaps. They enjoy chatting there.

Even though the man who has a cup of coffee at home, he still gets the same feeling when he has a cup of coffee in the café. It's coded that there is happiness inside while he's trying to drink a cup of coffee in the advertising image. And the quality of coffee aroma still gives the same strong aroma of the coffee product.

\section{REFERENCES}

Belch, G.E. \& Belch, Michael A. (2004). Advertising and promotion. New York: Mc Graw Hill Co.

Berger, A. Asa. (2010). Pengantar Semiotika: Tanda-Tanda Dalam Kebudayaan Kontemporer. Yogyakarta: Tiara Wacana

Dwita, D. \& Wijayani, I. (2018). “Gender Equality in Media Television: Semiotics Analysis of Fair and Lovely Advertisement issue of Marriage or Master Degree”, Komuniti, Vol.10, No.1. P.44-53

Littlejohn, S. W. (2009). Teori Komunikasi Theories of Human Communication edisi 9. Jakarta. Salemba Humanika.

Mayr, S. W. (2013). "Reading culture in TV commercials: A semiotic analysis of a TVcommercial for the purpose of teaching culture to foreign language students", International Journal of Arts and Commerce, Vol. 2(1). Pp: 86-100.

Perlmutter, D.M. (2011). What is sign language? Washington: Linguistic Society of America Press.

Prasojowati, M.W. \& Natsir, M. \& Ariani, S. (2019). "A Semiotic Analysis Found on the Cigarette Products", 
Mukhlasul Fasikh \& Abdul Muhid Murtadho

A semiotic analysis found on kopi kapal api special mix ramadhan edition advertisement

Jurnal Ilmu Budaya, Vol. 3, No. 1, P. 86-91

Tinarbuko, S. (2008). Semiotika

Komunikasi Visual. Yogyakarta. Jalasutra.

Sobur, A. (2013). Semiotika Komunikasi.

Bandung: Rosdakarya.

Sugiyono. (2009). Metode Penelitian Pendidikan Pendekatan Kuantitatif, dan Kualitatif, R\&D.Bandung: Alfabeta.

Wardhaugh, R. (2010). An Introduction to Sociolinguistics. New York: Mc Graw-Hill Inc. 